\title{
Gender differences in practicing standard precautions against blood-borne pathogens among surgeons at a tertiary care center: A cross-sectional study
}

Shahad Yousef Alsaigh, Amal Aboud Alasmari, Anadel Hassan Hakeem, Amairah Fahad Aloushan, Fatemah Saleh Bin Saleh, Alaa Althubaiti, Zeyad Yousef ${ }^{1}$

College of Medicine, King Saud Bin Abdulaziz University for Health Sciences, ${ }^{1}$ Department of Surgery, King Abdulaziz Medical City, National Guard Health Affairs, Riyadh, Saudi Arabia

\begin{tabular}{|c|}
\hline Access this article online \\
\hline Website: www.avicennajmed.com \\
\hline DOI: 10.4103/ajm.AJM_146_18 \\
\hline Quick Response Code: \\
$\square$
\end{tabular}

\begin{abstract}
Background: Surgeons are at an increased risk of contracting blood-borne pathogens. The aim of this study was to evaluate gender difference, surgical position, surgical experience, and subspecialty regarding surgeons' compliance to standard precautions. Methods: A cross-sectional questionnaire-based study was performed using a purposive sampling. A total of 241 surgeons were surveyed from June 2017 to January 2018. Results: In total, 179 (74.3\%) males and $62(25.7 \%)$ females completed the questionnaire. The gender difference was evident when the type of surgery was extremely important in influencing the decision on wearing double gloves (DGs); $108(60.3 \%)$ male surgeons versus $27(43.5 \%)$ female surgeons $(P=0.022)$. Although a total of $17(30.3 \%)$ surgeons reported being extremely and very concerned about contracting human immunodeficiency virus through their work, they had never tried DG $(P=0.027)$. Conclusion: This study revealed that the decision of wearing DG was affected by several factors. Surgeons' decision to wear DG was influenced by the type of surgery. This study showed that most surgeons reported lack of adherence to barrier precaution measures.
\end{abstract}

Key words: Barrier precautions, blood-borne pathogens, double gloving, surgeons, surgical positions, surgical specialty

\section{INTRODUCTION}

Blood-borne pathogens including human immunodeficiency virus (HIV), hepatitis B virus (HBV), and hepatitis $\mathrm{C}$ virus are occupational risks for health-care workers (HCWs) and are transmitted through blood and body fluids. ${ }^{[1-5]}$ Surgeons in particular are at a high risk of transmission of blood-borne pathogens due to invasive procedures they perform and blood contact. ${ }^{[1,2,4,5]}$ Therefore, the Center for Disease Control and Prevention (CDC) has established and recommended the standard precautions (formerly known as universal precautions) to protect surgeons and minimize

Address for correspondence: Dr. Shahad Yousef Alsaigh, College of Medicine, King Saud Bin Abdulaziz University For Health Sciences, Riyadh, Saudi Arabia.

E-mail: alsaigh535@ksau-hs.edu.sa the transmission of blood-borne pathogens. ${ }^{[2]}$ These recommendations include but not limited to hepatitis $\mathrm{B}$ vaccination, double gloves (DGs), changing gloves regularly, protective eyewear, and the use of blunt surgical needles. ${ }^{[1-5]}$

One of the most important precautions recommended by the $\mathrm{CDC}$ and several other guidelines specifically for surgeons is

This is an open access journal, and articles are distributed under the terms of the Creative Commons Attribution-NonCommercial-ShareAlike 4.0 License, which allows others to remix, tweak, and build upon the work non-commercially, as long as appropriate credit is given and the new creations are licensed under the identical terms.

For reprints contact: reprints@ @medknow.com

Cite this article as: Alsaigh SY, Alasmari AA, Hakeem AH, Aloushan AF, Saleh FS, Althubaiti A, et al. Gender differences in practicing standard precautions against blood-borne pathogens among surgeons at a tertiary care center: A cross-sectional study. Avicenna J Med 2019;9:15-22. 
the use of DGs. ${ }^{[2]}$ This simple protective measure has been proven by numerous studies and meta-analysis to significantly reduce the risk of transmission of blood-borne diseases for both surgeons and their patients. ${ }^{[6-14]}$ However, the level of compliance among surgeons in different surgical specialties has been evidenced to be low. ${ }^{[15-20]}$ According to Wright, it was reported that surgeons used DG in $32.2 \%$ of procedures. ${ }^{[18]}$ Furthermore, Patterson et al. found that $12 \%$ of surgeons used DG. ${ }^{[15]}$ In addition, orthopedic surgeons had the highest level of compliance with DG use compared to other surgical specialties. ${ }^{[15,17,19]}$ According to Fay et al., glove perforation risk was frequently associated with prolonged surgeries $(1-3 \mathrm{~h}$, $27 \%$ glove perforation risk; $3-5 \mathrm{~h}, 47 \%$ glove perforation risk; and $>5 \mathrm{~h}, 58 \%$ glove perforation risk). ${ }^{[21]}$ Most surgeons state decreased hand sensation and manual skills when wearing DG. ${ }^{[15,22]}$ However, a research published in 2010 used 2-point discrimination test when wearing no glove, single glove, and DG, and concluded that DG has no influence on hand sensation and manual skills. ${ }^{[23]}$ There is a high risk of glove perforation during surgery; therefore, using DG provides a second barrier and decreases blood leakage and contact with the skin of surgeons since most of them have skin abrasions due to repetitive scrubbing and handwashing. ${ }^{[8,11,14,21]}$

All these studies suggest that there were varying degrees of noncompliance to practice the standard precautions to prevent blood-borne pathogen transmission. ${ }^{[15,17,18,24-27]}$ Although surgeons perform high-risk procedures and are at high risk of acquiring blood-borne pathogens, only insignificant number of surgeons in different specialties practice the recommended prevention strategies such as wearing DG. ${ }^{[15,18,25-27]}$ Therefore, in this study, we assessed the surgeons' concerns and awareness of the practices of standard precautions in different surgical specialties in all surgical positions, with focus on highlighting possible gender differences.

\section{METHODS}

\section{Study design, setting, and subjects}

This study was a cross-sectional questionnaire carried out at King Abdulaziz Medical City in Riyadh (KAMC-R), Saudi Arabia. Surgeons who are specialized in cardiovascular, vascular, general, neurosurgery, ophthalmology, plastic, otolaryngology, urology, orthopedics, thoracic, obstetrics/ gynecology, and from different surgical positions including residents, associate consultants, fellows, and consultants were the targeted participants. Those who are specialized in oral and maxillofacial surgery or no longer working at KAMC-R were excluded from the study. A total of 241 surgeons were reached during the period from June 2017 to January 2018.

\section{Data collection}

After the modification and adoption of Wright's and Patterson's data collection form, the questionnaire was developed and used as a tool to evaluate surgeons' awareness, concerns, and adherence to the practices of standard precaution. ${ }^{[15,18]}$

In June 2017, the questionnaire initially was e-mailed to surgeons in an electronic Google Form followed by personal interviews due to the shortage of surgeons' responses. The questionnaire had the following four divisions: demographic information, frequency of using barrier precautions, reasons for not using barrier precautions, and factors influencing the decision to use DG. The demographic information included surgeons' age, sex, subspecialty, and surgical experience. Barrier precautions' assessment included face shields attached to surgical masks, goggles, full-face shields, DG, and triple gloving.

\section{Sample size and sampling technique}

Raosoft online calculator (http://www.raosoft.com/ samplesize.html) was used to calculate the minimum suggested sample size which was 175 . The criterion to calculate sample size was $3 \%$ margin of error, $95 \%$ confidence level, and 50\% response distribution among surgeons. Purposive sampling technique was used.

\section{Statistical analysis}

Descriptive statistics including the frequency and percentage calculation were used to compare the baseline demographics of male and female surgeons. In addition, comparison between different surgical positions and subspecialty was carried out by descriptive statistic calculation. Pearson's Chi-square test or Fisher's exact test was used to compare categorical variables. An independent sample $t$-test was used to compare continuous data. $P<0.05$ was considered to be statistically significant. Multiple logistic regression was used to determine independent significant predictors of using barrier precautions. Odds ratios (ORs) with 95\% confidence intervals (CIs) were expressed relative to a reference baseline category. Data were analyzed using the SPSS database (IBM SPSS Statistics, SPSS Inc., Chicago, IL, USA).

\section{RESULTS}

In total, 241 surgeons completed the questionnaire; there were $179(74.3 \%)$ men and $62(25.7 \%)$ women. The mean \pm standard deviation age of surgeons was $35.8 \pm 11.0$ and $33.3 \pm 9.1$ years for males and females, respectively. Table 1 summarizes the surgeons' characteristics. 


\section{Double glove use}

A total of 43 (17.8\%) surgeons stated that they always wear DG. Patients with active hepatitis or HIV constituted the main reasons to affect surgeons' decision on wearing DG as it was considered extremely important. In contrast, patients' gender, race, age, and marital status were deemed not important in affecting surgeons' decisions on wearing DG during surgery [Supplement Table 1]. The gender difference was evident when the type of surgery was extremely important in influencing the decision on wearing DG for 108 (60.3\%) male surgeons versus 27 (43.5\%) female surgeons $(P=0.022)$ [Table 2]. The mean period to become familiar with DG was 28.8 days according to surgeons who reported always wearing DG. Both male and female surgeons reported that the main reasons for not wearing DG were not necessary and decreased hand sensation [Supplement Table 2].

Gender was not associated with the proportion of procedures, in which surgeons used DG $(P=0.301)$. When

\begin{tabular}{|c|c|c|}
\hline & \multicolumn{2}{|c|}{ Gender } \\
\hline & Male & Female \\
\hline$n(\%)$ & $179(74.3)$ & $62(25.7)$ \\
\hline Mean age (years) $\pm S D$ & $35.8 \pm 11.0$ & $33.3 \pm 9.1$ \\
\hline \multicolumn{3}{|l|}{ Specialty, $n(\%)$} \\
\hline Cardiovascular surgery & $6(3.4)$ & 0 \\
\hline Neurosurgery & $14(7.8)$ & $3(4.8)$ \\
\hline Obstetrics/gynecology & $22(12.3)$ & $34(54.8)$ \\
\hline Pediatric surgery & $8(4.5)$ & $3(4.8)$ \\
\hline General surgery & $44(24.6)$ & $10(16.1)$ \\
\hline Orthopedic surgery & $23(12.8)$ & 0 \\
\hline Plastic surgery & $4(2.2)$ & $\mathrm{I}(\mathrm{I} .6)$ \\
\hline Otolaryngology & $19(10.6)$ & $5(8.1)$ \\
\hline Urology & $21(11.7)$ & 0 \\
\hline Thoracic surgery & 0 & I (I.6) \\
\hline Vascular surgery & $4(2.2)$ & $0(0)$ \\
\hline Ophthalmology & $14(7.8)$ & $5(8.1)$ \\
\hline \multicolumn{3}{|l|}{ Surgical position, $n(\%)$} \\
\hline Consultant & $43(24)$ & II (I7.7) \\
\hline Associate consultant & $14(7.8)$ & $5(8.1)$ \\
\hline Assistant consultant & $14(7.8)$ & $3(4.8)$ \\
\hline Fellow & $6(3.4)$ & $4(6.5)$ \\
\hline Resident & $98(54.7)$ & $38(61.3)$ \\
\hline Staff physician & $5(2.8)$ & I (I.6) \\
\hline Mean experience (years) $\pm S D$ & $8.6 \pm 8.8$ & $7.8 \pm 7.8$ \\
\hline
\end{tabular}

\begin{tabular}{|c|c|c|c|}
\hline \multicolumn{4}{|c|}{$\begin{array}{l}\text { Type of surgery as a factor influencing the surgeons' decision on } \\
\text { wearing double gloves }\end{array}$} \\
\hline Gender & $\begin{array}{l}\text { Extremely/very } \\
\text { important, } n(\%)\end{array}$ & $\begin{array}{l}\text { No concern/slightly or } \\
\text { moderately important, } n \text { (\%) }\end{array}$ & $\boldsymbol{P}$ \\
\hline Male & $108(60.3)$ & 7I (39.7) & 0.022 \\
\hline Female & 27 (43.5) & $35(56.5)$ & \\
\hline
\end{tabular}

The total number of surgeons, $n=24$ I surgeons were asked about DG trial, 45 (83.4\%) Consultants had higher rates of trying DG than 98 (72.1\%) residents; however the difference did not reach statistical difference $(P=0.124)$ [Supplement Table 3]. The mean age of surgeons who reported always wearing DG was 38.2 years $(P=0.007)$. Furthermore, surgical position was a statistically significant factor for always using DG $(P=0.003)$, in which a total of $14(10.3 \%)$ residents reported always using DG in all of their procedures in comparison to $17(31.5 \%)$ consultants (OR: 0.2, 95\% CI: 0.1-0.6) [Supplement Table 4]. Although a total of 17 (30.3\%) surgeons reported being extremely and very concerned about contracting HIV through their work, they had never tried double gloving $(P=0.027)$ [Table 3]. In comparison, a total of $11(4.6 \%)$ surgeons stated explicitly that they are not concerned about contracting HIV and used DG in $0 \%$ of their procedures $(P<0.001)$ [Table 4 ].

Surgeons' age, gender, and surgical position did not have an impact on trying DG $(P=0.155,0.548$, and 0.124 , respectively). A total of 62 (84.9\%) surgeons with surgical experience more than 11 years had tried DG unlike 123 (73.2\%) surgeons with less surgical experience $(P=0.004)$.

Multiple logistic regression analysis was performed to assess the factors associated with the proportion of procedures in which surgeons used DG. Results showed that surgical subspecialty was the only significant, independent predictor of always using DG. Orthopedic surgeons had markedly higher odds of double gloving relative to all other subspecialties (OR: 21.8, 95\% CI: 6.8-70.6, $P<0.001$ ) [Figure 1].

\section{Barrier precautions}

The majority of surgeons answered not necessary when asked about the reasons for not using barrier precautions

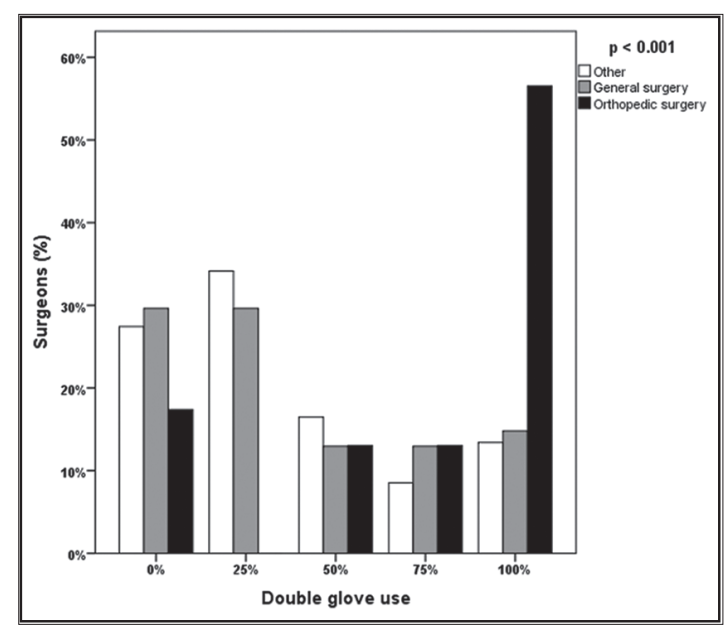

Figure 1: Subspecialty influence on the frequency of use of double gloving during surgery 
Alsaigh, et al:: Gender differences among surgeons

\begin{tabular}{|c|c|c|c|c|c|c|}
\hline \multirow{2}{*}{$\begin{array}{l}\text { Have you ever tried a } \\
\text { period of double gloving? }\end{array}$} & \multicolumn{5}{|c|}{ How concerned are you about contracting HIV through your work? } & \multirow[t]{2}{*}{$\boldsymbol{P}$} \\
\hline & Extremely, $n$ (\%) & Very, $n$ (\%) & Moderately, $n$ (\%) & Slightly, $n$ (\%) & No concern, $n(\%)$ & \\
\hline Yes & $74(40.0)$ & $28(15 . I)$ & $3 \mid(16.8)$ & $40(21.6)$ & $12(6.5)$ & 0.027 \\
\hline No & $11(19.6)$ & $6(10.7)$ & $15(26.8)$ & $19(33.9)$ & $5(8.9)$ & \\
\hline
\end{tabular}

\begin{tabular}{|c|c|c|c|c|c|c|}
\hline \multirow{2}{*}{$\begin{array}{l}\text { How concerned are you about } \\
\text { contracting HIV through your work? }\end{array}$} & \multicolumn{5}{|c|}{ Percentage of operations in which surgeons used double gloves, $n(\%)$} & \multirow[t]{2}{*}{$\boldsymbol{P}$} \\
\hline & $0 \%$ & $25 \%$ & $\mathbf{5 0} \%$ & $75 \%$ & $100 \%$ & \\
\hline Extremely & $17(7.1)$ & $12(5.0)$ & $24(10.0)$ & $14(5.8)$ & $18(7.5)$ & $<0.001$ \\
\hline Very & $7(2.9)$ & $7(2.9)$ & $5(2.1)$ & $4(1.7)$ & II (4.6) & \\
\hline Moderately & II (4.6) & $22(9.1)$ & $4(1.7)$ & $2(0.8)$ & $7(2.9)$ & \\
\hline Slightly & $19(7.9)$ & 27 (II.2) & $3(1.2)$ & $4(1.7)$ & $6(2.5)$ & \\
\hline No concern & II (4.6) & $4(1.7)$ & I (0.4) & $0(0.0)$ & $\mathrm{I}(0.4)$ & \\
\hline
\end{tabular}

[Supplement Table 2]. HBV vaccination was completed by most of the surgeons (96\% in males and $97 \%$ in females, $P=0.672)$. The gender difference was obvious when a total of $12(6.7 \%)$ male surgeons reported using goggles in all of their procedures compared to $2(3.2 \%)$ female surgeons $(P=0.034)$ [Table 5]. Surgeons' characteristics were not significantly associated with all other barrier precautions.

Multiple logistic regression analysis was performed to assess the factors associated with the proportion of procedures in which surgeons used goggles or triple gloving. Results showed that surgical experience and surgical subspecialty were significant and independent predictors of always using goggles and triple gloving. Surgeons with $>11$ years of experience had higher odds of using goggles relative to surgeons with less surgical experience (OR: 9.7, 95\% CI: $2.6-36.2, P=0.001)$. Orthopedic surgeons had higher odds of triple gloving compared to all other subspecialties (OR: 12.1, 95\% CI: 1.9-77.1, $P=0.008$ ).

\section{Willingness to adopt preventive strategies}

Majority of male $(169,94.4 \%)$ and female $(57,91.9 \%)$ surgeons stated that they are willing to modify their surgical technique if evidenced preventive strategies were made available [Supplement Table 5].

\section{DISCUSSION}

Surgeons are at an increased risk of exposure to bloodborne viruses due to their work nature in close contact with blood. ${ }^{[1,2,4,5]}$ Therefore, the CDC has designed and implemented the standard precautions as a measurement to protect surgeons from blood-borne pathogens. ${ }^{[2]}$ However, surgeons do not seem to realize that as it has been clearly proven by this study and previous other studies which

\begin{tabular}{|c|c|c|c|c|c|c|}
\hline \multicolumn{7}{|c|}{$\begin{array}{l}\text { Table 5: Reported percentages of goggles' use in relation } \\
\text { to surgeons' gender }\end{array}$} \\
\hline \multirow[t]{2}{*}{ Gender } & \multicolumn{6}{|c|}{$\begin{array}{l}\text { Percentage of operations in which surgeons used } \\
\text { goggles, } n(\%)\end{array}$} \\
\hline & $0 \%$ & $25 \%$ & $50 \%$ & $75 \%$ & $100 \%$ & $\boldsymbol{P}$ \\
\hline Male & $86(48.0)$ & $62(34.6)$ & $8(4.5)$ & II (6.2) & $12(6.7)$ & 0.034 \\
\hline Female & $24(38.7)$ & $23(37.1)$ & $10(16.1)$ & $3(4.8)$ & $2(3.2)$ & \\
\hline
\end{tabular}

revealed low adherence to CDC standard precaution guidelines. ${ }^{[13,15,18,24-27]} \mathrm{HBV}$ vaccine is necessary for HCWs, especially surgeons. ${ }^{[2]}$ Other studies have found low HBV vaccination status among surgeons. ${ }^{[15,28-31]}$ However, in this study, $96 \%$ of male and $97 \%$ of female surgeons were vaccinated to $\mathrm{HBV}$.

Surgeons according to previous studies do not frequently use DG. ${ }^{[15-20]}$ In this study, only 43 (17.8\%) surgeons stated that they always wear DG, which demonstrate the lack of initiation and neglect among surgeons. Gloves provide an additional level of protection against blood and body fluid transmission for both the surgeon and the patient. ${ }^{[6-14,21]}$ This highlights the importance of wearing DG as the second glove can provide protection if the first glove tears. It was noticed in this study that wearing DG is case dependent, i.e., it was higher in infected patients such as HIV and HBV patients [Supplement Table 1].

Surgeons deal with sharp instruments that put them at a greater risk of glove perforation, especially with longer operations, which could have been easily prevented by a simple measure which is using DG. ${ }^{[6-14,21]}$ This emphasizes that more policies should be developed to reinforce surgeons' practice of standard precautions. The main justification provided by surgeons for not using barrier precaution was 
not necessary and decreased hand sensation, consistent with the results of previous studies [Supplement Table 2]. ${ }^{[15,22]}$ There might be some inconvenience reported by surgeons when first trying DG. However, the average time for a surgeon to get used to DG was 28.8 days according to surgeons who reported always wearing DG. This indicates that there might be a transitional period for the surgeon to adapt to using DG and reach optimal manual dexterity.

It is interesting to note that orthopedic surgeons were more likely to use triple gloves compared to other specialties. This might be explained by the gender bias in this group of surgeons as all of them were males [Table 1], and as this was evident in the gender difference in the reported use of triple gloving.

The results of this study were not novel as Wright et al. and Patterson et al. reached the same conclusion which was made approximately 20 years ago and still no improvement has been noticed. ${ }^{[15,18]}$ This shows that surgeons have the awareness, but they do not want to act on it. Modern-time surgeons still resist the change and compliance to standard precautions' practices.

More education and promotion to implement CDC guidelines among surgeons is a necessity for every hospital executive which may hopefully increase the compliance with protection against blood-borne diseases. Senior surgeons should educate and encourage junior surgeons to wear DG so as to ensure compliance among everyone in the surgical team.

One of the study limitations is that some answers may not actually reflect the reality of barrier precautions' practices by surgeons since this study used a self-reported questionnaire, i.e., surgeons were not always meticulously answering the questionnaire. In addition, this study addressed the frequency of barrier precaution practices throughout the surgeons' career, which makes recall bias highly likely. In comparison to international surveys, small sample size was included in this study; therefore, it is suggested to implement multicentric national survey to conclude generalizable accurate results.

\section{CONCLUSION}

This study revealed that the decision of wearing DG was affected by several factors i.e. surgeons are more inclined to wear DG when encountering hepatitis- or HIV-positive patients. Female and male surgeons' decision to wear DG was influenced by the type of surgery, but it was more significant in male surgeons. Senior surgeons were more likely to wear DG than juniors. This study showed that while most surgeons reported lack of adherence to barrier precaution, surgeons reported the willingness to try these preventive strategies if proven by evidence. This requires further surgeons' education about the importance of adherence to these strategies and techniques. In addition, more research is recommended to highlight the significant effect of these strategies on patients and surgeons.

\section{Financial support and sponsorship}

Nil.

\section{Conflicts of interest}

There are no conflicts of interest.

\section{REFERENCES}

1. Watson DS. Perioperative Safety E-Book. $1^{\text {st }}$ ed. St. Louis, MO: Elsevier Health Sciences; 2011.

2. Siegel JD, Rhinehart E, Jackson M, Chiarello L, Health Care Infection Control Practices Advisory Committee 2007 guideline for isolation precautions: Preventing transmission of infectious agents in health care settings. Am J Infect Control 2007;35:S65-164.

3. Bloodborne Pathogens - Occupational Exposure; 2013. Available from: https://www.cdc.gov/oralhealth/infectioncontrol/bloodborne_ exposures.htm. [Last accessed on 2018 Jan 23].

4. Updated CDC Recommendations for the Management of Hepatitis B Virus-Infected Health-Care Providers and Students; 2012. Available from: https://www.cdc.gov/mmwr/preview/mmwrhtml/rr6103a1.htm. [Last accessed on 2018 Jan 23].

5. Deuffic-Burban S, Delarocque-Astagneau E, Abiteboul D, Bouvet E, Yazdanpanah Y. Blood-borne viruses in health care workers: Prevention and management. J Clin Virol 2011;52:4-10.

6. Tanner J, Parkinson H. Double Gloving to Reduce Surgical CrossInfection. Cochrane Database Syst Rev 2006;(3). Art. No. CD003087.

7. Childs T. Use of double gloving to reduce surgical personnel's risk of exposure to bloodborne pathogens: An integrative review. AORN J 2013;98:585-96000000.

8. Na'aya HU, Madziga AG, Eni UE. Prospective randomized assessment of single versus double-gloving for general surgical procedures. Niger J Med 2009;18:73-4.

9. Birnbach DJ, Rosen LF, Fitzpatrick M, Carling P, Arheart KL, Munoz-Price LS, et al. Double gloves: A randomized trial to evaluate a simple strategy to reduce contamination in the operating room. Anesth Analg 2015;120:848-52.

10. Korniewicz D, El-Masri M. Exploring the benefits of double gloving during surgery. AORN J 2012;95:328-36.

11. Guo YP, Wong PM, Li Y, Or PP. Is double-gloving really protective? A comparison between the glove perforation rate among perioperative nurses with single and double gloves during surgery. Am J Surg 2012;204:210-5.

12. Wittmann A, Kralj N, Köver J, Gasthaus K, Hofmann F. Study of blood contact in simulated surgical needlestick injuries with single or double latex gloving. Infect Control Hosp Epidemiol 2009;30:53-6.

13. Matta H, Thompson AM, Rainey JB. Does wearing two pairs of gloves protect operating theatre staff from skin contamination? BMJ 1988;297:597-8.

14. Hagen GØ, Arntzen H. The risk of surgical glove perforations. Tidsskr Nor Laegeforen 2007;127:856-8.

15. Patterson JM, Novak CB, Mackinnon SE, Patterson GA. Surgeons' concern and practices of protection against bloodborne pathogens. 
Ann Surg 1998;228:266-72.

16. Moghimi M, Marashi SA, Kabir A, Taghipour HR, Faghihi-Kashani AH, Ghoddoosi I, et al. Knowledge, attitude, and practice of iranian surgeons about blood-borne diseases. J Surg Res 2009;151:80-4.

17. Haines T, Stringer B, Herring J, Thoma A, Harris KA. Surgeons' and residents' double-gloving practices at 2 teaching hospitals in ontario. Can J Surg 2011;54:95-100.

18. Wright JG, Young NL, Stephens D. Reported use of strategies by surgeons to prevent transmission of bloodborne diseases. CMAJ 1995;152:1089-95.

19. Akduman D, Kim LE, Parks RL, L'Ecuyer PB, Mutha S, Jeffe DB, et al. Use of personal protective equipment and operating room behaviors in four surgical subspecialties: Personal protective equipment and behaviors in surgery. Infect Control Hosp Epidemiol 1999;20:110-4.

20. Cutter J, Jordan S. Inter-professional differences in compliance with standard precautions in operating theatres: A multi-site, mixed methods study. Int J Nurs Stud 2012;49:953-68.

21. Fay MF, Dooher DT. Surgical gloves. Measuring cost and barrier effectiveness. AORN J 1992;55:1500-3, 1507, 1510-9.

22. St Germaine RL, Hanson J, de Gara CJ. Double gloving and practice attitudes among surgeons. Am J Surg 2003;185:141-5.

23. Fry DE, Harris WE, Kohnke EN, Twomey CL. Influence of double-gloving on manual dexterity and tactile sensation of surgeons. J Am Coll Surg 2010;210:325-30.

24. Al-Zahrani AO, Farahat F, Zolaly EN. Knowledge and practices of healthcare workers in relation to bloodborne pathogens in a tertiary care hospital, Western Saudi Arabia. J Community Health 2014;39:959-64.
25. Hammond JS, Eckes JM, Gomez GA, Cunningham DN. HIV, trauma, and infection control: Universal precautions are universally ignored. J Trauma 1990;30:555-8.

26. Maniar HH, Tawari AA, Suk M, Bowen TR, Horwitz DS. Percutaneous and mucocutaneous exposure among orthopaedic surgeons: Immediate management and compliance with CDC protocol. J Orthop Trauma 2015;29:e391-4.

27. McCarthy ML, Bosse MJ, Preas MA, De Long WG, Gunther SF, Moed BR, et al. Orthopedic trauma surgeons' attitudes and practices towards bloodborne pathogens. J Orthop Trauma 1996;10:383-8.

28. Alqahtani JM, Abu-Eshy SA, Mahfouz AA, El-Mekki AA, Asaad AM. Seroprevalence of hepatitis $B$ and $C$ virus infections among health students and health care workers in the Najran region, Southwestern Saudi Arabia: The need for national guidelines for health students. BMC Public Health 2014;14:577.

29. Mueller A, Stoetter L, Kalluvya S, Stich A, Majinge C, Weissbrich B, et al. Prevalence of hepatitis B virus infection among health care workers in a tertiary hospital in Tanzania. BMC Infect Dis 2015;15:386.

30. Kisic-Tepavcevic D, Kanazir M, Gazibara T, Maric G, Makismovic N, Loncarevic G, et al. Predictors of hepatitis B vaccination status in healthcare workers in Belgrade, Serbia, December 2015. Euro Surveill 2017;22: pii: 30515.

31. Maggiore U, Scala C, Toletone A, Debarbieri N, Perria M, D'Amico B, et al. Susceptibility to vaccine-preventable diseases and vaccination adherence among healthcare workers in Italy: A cross-sectional survey at a regional acute-care university hospital and a systematic review. Hum Vaccin Immunother 2017;13:470-6. 


\begin{tabular}{|c|c|c|c|c|c|}
\hline \multicolumn{6}{|c|}{ Supplement Table I: Factors that affect surgeons' decision to double glove } \\
\hline Patient factors & $\begin{array}{c}\text { Extremely } \\
\text { important, } n \text { (\%) }\end{array}$ & $\begin{array}{c}\text { Very important, } \\
n(\%)\end{array}$ & $\begin{array}{c}\text { Moderately } \\
\text { important, } n(\%)\end{array}$ & $\begin{array}{c}\text { Slightly } \\
\text { important, } n \text { (\%) }\end{array}$ & $\begin{array}{c}\text { Not important, } \\
n(\%)\end{array}$ \\
\hline Patients' gender & $14(5.8 \mathrm{I})$ & $7(2.9)$ & $19(7.9)$ & $14(5.8)$ & $187(77.6)$ \\
\hline Patients' race & $12(5.0)$ & $18(7.5)$ & $24(10.0)$ & $19(7.9)$ & $168(69.7)$ \\
\hline Patients' age & $14(5.8)$ & $21(8.7)$ & $32(13.3)$ & $20(8.3)$ & $154(63.9)$ \\
\hline Patients' marital status & $18(7.5)$ & $16(6.6)$ & $42(17.4)$ & $26(10.8)$ & 139 (57.7) \\
\hline Hospital & $38(15.8)$ & $39(16.2)$ & $46(19.9)$ & $25(10.37)$ & $93(38.6)$ \\
\hline Type of surgery & $82(34.0)$ & $53(22.0)$ & $46(19.1)$ & $13(5.4)$ & $47(19.5)$ \\
\hline Trauma case & $92(38.2)$ & $56(23.2)$ & $43(17.8)$ & $7(2.9)$ & $43(17.8)$ \\
\hline Patient - known IV drug user & $179(74.3)$ & $27(11.2)$ & $14(5.8)$ & $3(1.2)$ & $18(7.5)$ \\
\hline Patient - known HIV infection & $218(90.5)$ & $6(2.5)$ & $4(1.7)$ & I (0.4) & $12(5.0)$ \\
\hline Patient - with active hepatitis & $212(87.9)$ & $12(5.0)$ & $3(1.2)$ & $2(0.8)$ & $12(5.0)$ \\
\hline
\end{tabular}

\begin{tabular}{|c|c|c|c|c|c|c|}
\hline \multicolumn{7}{|c|}{ Supplement Table 2: Surgeons' justifications for not using barrier precautions } \\
\hline Barrier precaution & $\begin{array}{c}\text { Not } \\
\text { available, } \\
n(\%)\end{array}$ & $\begin{array}{c}\text { Not } \\
\text { necessary, } \\
n(\%)\end{array}$ & $\begin{array}{c}\text { Not } \\
\text { comfortable, } \\
n(\%)\end{array}$ & $\begin{array}{c}\text { Fogging (for } \\
\text { protective } \\
\text { eyewear), } n \text { (\%) }\end{array}$ & $\begin{array}{c}\text { Interfered } \\
\text { with surgery, } \\
n(\%)\end{array}$ & $\begin{array}{c}\text { More than } \\
\text { one answer, } \\
n(\%)\end{array}$ \\
\hline Face shields attached to surgical mask & $4(1.6)$ & $73(30.2)$ & $67(27.8)$ & $53(21.9)$ & $9(3.7)$ & $33(14.5)$ \\
\hline Goggle & $13(5.3)$ & $93(38.5)$ & $49(20.3)$ & $41(17.0)$ & II (4.5) & $34(14.0)$ \\
\hline Full face shields & $32(13.2)$ & $86(35.6)$ & $68(28.2)$ & $24(9.9)$ & $6(2.4)$ & $25(10.3)$ \\
\hline Double gloving & $8(3.3)$ & $87(36.1)$ & 77 (31.9) & $4(1.6)$ & 28 (II.6) & 37 (I5.9) \\
\hline Triple gloving & $7(2.9)$ & $120(49.7)$ & $46(19.0)$ & $\mathrm{I}(0.4)$ & $31(12.8)$ & $36(14.9)$ \\
\hline
\end{tabular}

\begin{tabular}{|c|c|c|c|}
\hline \multicolumn{4}{|c|}{$\begin{array}{l}\text { Supplement Table 3: The reported percentages of } \\
\text { double glove trial in relation to surgical position }\end{array}$} \\
\hline \multirow[t]{2}{*}{ Surgical position } & \multicolumn{3}{|c|}{$\begin{array}{l}\text { Have you ever tried a period of double } \\
\text { gloving? }\end{array}$} \\
\hline & Yes, $n$ (\%) & No, $n$ (\%) & $P$ \\
\hline Consultant & $45(83.4)$ & $9(16.7)$ & 0.124 \\
\hline Associate consultant & $18(94.8)$ & I (5.3) & \\
\hline Assistant consultant & II (68.8) & $5(3 \mid .3)$ & \\
\hline Fellow & $9(90.0)$ & I (I0.0) & \\
\hline Resident & $98(72.1)$ & $38(27.9)$ & \\
\hline Staff physician & $4(66.6)$ & $2(33.3)$ & \\
\hline
\end{tabular}


Alsaigh, et al:: Gender differences among surgeons

\begin{tabular}{|c|c|c|c|c|c|c|}
\hline \multicolumn{7}{|c|}{ Supplement Table 4: Reported percentages of double glove use in relation to surgical position } \\
\hline \multirow[t]{2}{*}{ Surgical position } & \multicolumn{6}{|c|}{ Percentage of operations in which surgeons used double gloves, $n(\%)$} \\
\hline & $0 \%$ & $25 \%$ & $50 \%$ & $75 \%$ & $100 \%$ & $\boldsymbol{P}$ \\
\hline Consultant & $14(25.9)$ & $17(3 \mid .5)$ & $2(3.7)$ & $4(7.4)$ & $17(3 \mid .5)$ & 0.003 \\
\hline Associate consultant & I (5.3) & $4(21.1)$ & $3(15.1)$ & $5(26.3)$ & $6(31.6)$ & \\
\hline Assistant consultant & $5(3 \mid .3)$ & $7(43.8)$ & I (6.3) & $0(0.0)$ & $3(18.8)$ & \\
\hline Fellow & I (10.0) & $2(20.0)$ & $2(20.0)$ & $2(20.0)$ & $3(30.0)$ & \\
\hline Resident & $41(30.2)$ & 39 (28.7) & $29(21.3)$ & $13(9.6)$ & $14(10.3)$ & \\
\hline Staff physician & $3(50.0)$ & $3(50.0)$ & $0(0.0)$ & $0(0.0)$ & $0(0.0)$ & \\
\hline
\end{tabular}

Total number of surgeons, $n=24$ I

$\begin{aligned} & \text { Supplement Table 5: Number and percentage of surgeons } \\
& \text { who were interested to adopt preventive strategies }\end{aligned}$
\begin{tabular}{llll}
\hline Would you change the way you & Male & Female & $P$ \\
performed surgery if proven preventive & & & \\
strategies were made available? & & & \\
\hline Yes, $n(\%)$ & $169(94.4)$ & $57(91.9)$ & 0.49 \\
No, $n(\%)$ & $10(5.6)$ & $5(8.1)$ & \\
\hline
\end{tabular}

